\title{
Disability and Its Origination
}

\author{
Shahid Hussain Sheikh* \\ NIDS Treatment \& Research Center Trust, Pakistan
}

Submission: March 15, 2017; Published: March 24, 2017

*Corresponding author: Shahid Hussain Sheikh, Chairman, NIDS Treatment \& Research Center Trust, 126 Habitat Shadman II, Nr. Jail RD, Lahore, Pakistan, Tel: 92-300-481-6677; Email: Profdrshahid@gmail.com

\section{Opinion}

The disabilities may very well be defined as a "state of nonfunctionality". It may be a temporary or permanent. Disability may be caused by accident or developmental anomaly or disruption of anatomical and/or physiological homeostasis on the system level, organ level, tissue level, cellular level or Nucleus level. To date, all healthcare disciplines Allopathy, Homeopathy, Alternative medicine and others stop their investigation to diagnose at cellular level. Cells are controlled by the nucleus. Nobody has yet further investigated the contribution of "Nucleopathy" into the malfunctioning of the system that signifies the phenomena of "Symptomatology". The urgency of settlement of the symptomatology has compelled the healthcare system to continue to develop advancements in its alleviation that is now thought to be the best available solution for the quality healthcare. Therefore, the symptomatic treatment has prevailed out of bounds worldwide. It is thought, that by relieving symptoms, the quality of life has been rendered to the patient. In fact, it is a chance given to the domestic immunity to eventually re-congregate/strengthen and combat the pathogen that is causing the symptom/s by providing a temporary relief.

In other cases, if the symptoms are not alleviated, then, interventional remedies and procedures are deployed to offset the disruption of the homeostasis. i.e. invasive and non-invasive procedures bypass, stents, shunts, pace makers, defibrillators implants, deep brain stimulators. Permanent remedies for Diabetes Mellitus, Hypertension, certain oncological ailments etc. Permanent usage of medicine, therapies and/or technological tools are very well a temporary life support for the patients, but at the same time it's a shear evidence of poor knowledge of the disability.

Many interventional and remedial tools are simply the hard evidence of failure of our complete understanding of the real root cause/s and its prevalence that has established the anatomical and physiological "Disability".

To best understand the phenomena of Disability, we need to review the life and developmental process from the inception to the developmental schematics, where we can possibly intervene and save the new human being from all kinds of possible ailments and disabilities. As it's already understood, that the brain hosts the ultimate controlling and management capabilities of all the systems, from development to timely functionality. The developmental anomalies however take place within intrauterine lifespan, if not already miscarried, other dysfunctions may be post-partum.

A pure Sperm and a pure Ovum inception natural or in vitro must warrant a successful development journey for a new life. But this does not happen $100 \%$ of the time. Majority of the time both sperm and ovum are generally contaminated with the most devastating viral virion passed on from the parent to the zygote. Of course, this may be outside the scope of practice of OB \& GYN and geneticists, but the root cause is right here. The development begins, Mitosis further more takes the influence and the genome of the neuro-virus from cell to cell all in first trimester; as the brain \& Spinal cord are being constructed in this time frame. Now the immunity of the mother has to be real robust to support the embryonic development and combat the growing viral genome at the same time.

If the viral genome win, miscarriage will take place at any stage or Sudden Death Syndrome post-partum. If the mother's immunity is robust and wins, a normal baby is naturally delivers, but may be with sub clinical symptomatology. Pediatrician's and pediatric Neurologists are not yet aware of this war. Therefore, various nomenclatures are used to explain the fetal disabilities from intrauterine hypoxia, late milestone, autism, ADD, ADHD, Microcephaly, Hydrocephaly, cerebral edema, visual impairment and Cerebral Palsy. If the baby is born eventless, at the early age Psycho Somatic symptomatology appears and patient enters the Psychiatric discipline to help live a normal life. Eventually, short term memory, speech, behavior and other deficits come into play.

But the grass root problem that started from the get go has not been screened or checked. Interestingly, it will congenially transform into the next generation if not treated before the adulthood. 
Now there is high percentage rate increase of the following:
a) Infertility (Both Male \& Female).
b) Miscarriages.
c) Special Children / Disable Children.
d) Adult Mental \& Physical Disability.
e) Prevailing chronic ailments.
f) Short Life Expectancy.
g) Low performance in working.

h) Low academic Achievement.

i) High crime rate \& violence.

j) Domestic violence \& Divorce rate.

Subnucleus Neuro pathology is the paradigm shift in the conventional way of diagnosing any ailment. Disability temporary or permanent substantiates itself right from the grass roots if the nucleopathy of the controlling neurons is taken into consideration. Almost all physiological disabilities can be reversed at any age if diagnosed properly. All interested physicians are welcome for scientific collaboration to best provide this new service to their community gain quality of life.

\section{Your next submission with Juniper Publishers will reach you the below assets}

- Quality Editorial service

- Swift Peer Review

- Reprints availability

- E-prints Service

- Manuscript Podcast for convenient understanding

- Global attainment for your research

- Manuscript accessibility in different formats

( Pdf, E-pub, Full Text, Audio)

- Unceasing customer service

Track the below URL for one-step submission https://juniperpublishers.com/online-submission.php 